\title{
The Childhood Betrayal and Hope Regained in Stephen \\ King's The Institute
}

Anas P M

M.Phil Scholar

Department of English

Sree Narayana Guru College

Coimbatore, Tamil Nadu, India

anaspm786@gmail.com

Dr. A.J Manju

Associate Professor and Head

M.A., M.Phil., Ph.D., B.Ed.,

Sree Narayana Guru College

Coimbatore, Tamil Nadu, India

manjumadhu57@gmail.com

\section{Abstract}

Childhood is a time worth remembering in everyone's life. We all cherish the beautiful memories and fun we had in our childhood once we're old. We never know the real value of a moment until it becomes a memory. Even now we are happy to go back to those places where we have spent our childhood. Thinking about it fills our heart with nostalgic feelings. But have you ever thought about children who never had such a beautiful childhood as yours? This novel takes us to those children who are being kidnapped from their parents and sent into a frightening government facility called 'The Institute' for gifted children! The Institute 
(2019) is a science fiction horror novel written by Stephen King. It is one of his terrifying novels yet. Many of his works are transformed into movies and television series.

The main focus of this novel is on the childhood betrayal done by the authorities running the Institute, and the survival of the children. The story is written by taking the ideas of a fictional child abusing institution where gifted children from all over the country are taken in and they are being forced to undergo dreadful medical experiments. Most of the children have super powers of Telepathy or Telekinesis. The officials running the Institute want the children to get control over their powers and to master them, so that they can be used in wars. They can be used as weapons against terrorists, and as mind readers. The doctors don't treat them like humans. To them they are merely test subjects. The government kills any test subjects it can't control because only then it can keep the country safe. There is no hope of escape for the children, yet they are all finally escaped by the brave efforts of Luke Ellis, the main character in the novel and his friends.

Keywords: Childhood, Children, Child abuse, Hope, Telepathy, Telekinesis, Friendship Introduction

The story takes place in the fictional town of DuPray, Minnesota. The protagonist of the story is a 12 year old boy named Luke Ellis who lives with his parents on a quiet suburban street. He was a gifted student already enrolled in the MIT classes. Luke also had some super powers of moving things with his mind (Telekinesis). His powers get triggered whenever he is angry or frustrated. His parents always worry about him because life isn't that much easy for a gifted child with superpowers. They motivate him to keep his power a secret, but this made things worse. All he wanted was to live a normal life like other children and have real friends. A night to forget 
One night everything turned upside down. A black SUV drove up to his house. Some strange men jump out. They killed his parents and kidnapped Luke by triggering an aerosol can to his face which knocked him out. Next morning Luke woke up in a room identical to his own, but it had no windows. All his personal belongings were there. Soon he realised that it was not his room, not even his house. He began to wonder what happened to his parents. Soon he met other children like him and made friends with Kalisha, George, Nick, Iris and Avery. Some of them can read minds, others can operate fire and a very few had telekinetic powers. Luke learned out many things regarding this secret facility called the Institute. No child has ever escaped from the Institute and there was no hope of escape! No one cared about whether he is intelligent or not. All that the officials wanted to test is how strong his telekinetic power is. Every child had their own rooms at the Institute. There were room cleaning staffs, doctors, lab technicians, etc. There were canteens and play areas for the children to spend their leisure time.

Mrs Sigsby was the head of the Institute. Luke's room is in what is known as the Front Half of the Institute. The Front Half is where all the new children are taken in for all the medical experiments, and were all the brightest children live. The Back Half is where all the disruptive and disorderly children are sent. No one knows what happens to the children in the Back Half. All they do know is that no one ever sees the children after they go to the Back Half. Luke doesn't want to go to the Back Half. His friends told him that the only way to survive in the Institute was to obey what the staffs tell him to do and behave well to them. By doing this they will get tokens which can be used to buy snacks and whatever food they like from the canteen in the Institute. They warned him about Mrs Sigsby and never to disobey her. She only cares about extricate power from the children; if she can't make the children do what she wants, they will be terminated!

The beginning of the worse 
As the days passed Luke had to undergo awful medical experiments. The doctors don't treat him like a human. To them he is only a test subject. They punished him for not being able to gather and control his power through dreadful ways like drowning him in a tank full of water, isolating him from the others, injecting him with various medicines, and finally abused him by not allowing to eat or sleep. His friends had gone one by one to the Back Half. He can do nothing, but to watch his friends leaving him, at last only Luke and Avery was left in the Front Half. He knows that it is only a matter of time before he ends up there too. He was not able to summon his power or to get control over it. Readers should know that there is direct violence against children in the book. As majority of his friends had gone to the Back Half Luke felt lonely and isolated.

The great escape

Luke found out a way to overcome his boredom by helping out a maid named Maureen in her daily chores of cleaning rooms and canteen. He doesn't know the fact that Maureen was a snitch for Mrs Sigsby. But Maureen have some compassion for Luke as he helped her to find a way for clearing off her financial debts. Luke soon develops weak telepathic abilities as a result of the experiments, but keeps it a secret. After Kalisha had gone to the Back Half, she was able to send telepathic messages to Avery whose powers of telepathy are off the scale. Luke managed to get the information regarding Back Half from Kalisha through Avery. Luke comes to know that in Back Half the children's collective powers are used to assassinate individuals until the strain kills them. Luke becomes craving to escape and get help for the other children.

One day Maureen helped Luke by passing the information that the chainlink fence in the play area has a weak spot which can be used to crawl outside, and on one night while everyone was sleeping, he started to dig under the chain link fence by using a scoop. He scraped the scoop against the bottom of the chain link repeatedly until he had a trench 
under the bottom of the fence. But when he lay down and tried to slide under, the fence stopped him. It wasn't even close. Luke got on his knees again and dug more and finally he was out! He removed the tracking device which they had put on his right earlobe by using the knife which Maureen had given him. Later Maureen commits suicide in order to hide the fact that Luke is missing. The Institute's security took 24 hours to realise Luke's escape.

Hope is not dead

At that time Luke was on a train to DuPray. A hotel owner who was a snitch saw Luke and informed the Institute that Luke was in town. Meantime Luke convinced Tim Jamieson and other police officials whom he had met on his way about his story and gives the sheriff a Pen drive containing a confession from Maureen along with videos taken secretly from the Back Half by Maureen which persuaded the police officers to help him. The Institute knew Luke was in a police station and they decided to kill him at any cost. After some time several men arrived from the Institute following a shoot - out, several police men including Mrs Sigsby and a doctor from the Institute are heavily injured. Tim Jamieson and Luke captured Mrs Sigsby back in to the Institute where her deputy, a man named Stackhouse tried to ambush them. Since Mrs Sigsby was driving the car, she was killed accidentally.

As Luke was away from the Institute Avery was sent to the Back Half for helping Luke. Avery and the other children in the Back Half was trapped by Stackhouse and ordered to kill them all using a poisonous gas made from the cleaning chemicals. As the gas is released, Avery, Kalisha, Iris, George, Nick and the others joined together and fought back. They used their minds to hover areas of the Institute into the air. Kalisha, George, Nick and Helen escaped, but the others were killed as the hallway they were trapped in 
collapsed. All Institute staffs are killed in the crash and Tim took Luke and the other survivors with him. Months later they are visited by Mrs Sigsby’s supervisor, asking them not to disclose the information in the pen drive about the Institute for the public. He argued lot about the need of Institutes like the one that they destroyed. The man leaves Luke and his friends alone for the promise that the public will not know anything about the Institute. The pen drive is kept hidden in a safe, with each of the surviving children holding a key. Conclusion

All of us have two choices in life. One is to surrender and give up and the second is to think positive and hope for good. As something is better than nothing, always do something to get out of the puzzle. The Institute by Stephen King is a novel which tells us that we should not delay doing things in life. Just do them. Your life is all in your hands so take responsibility of your life and the God will do the rest. If Luke had waited for someone to come and help him doing nothing he and the others will be dead. The novel also shows us how extreme evil can be hidden inside some humans and despite all the tragedies how hope can transform a person.

The novel makes us realise of all the facilities and freedom we all get in our life. It is also a novel that can be read with much interest for all. If it's once read, you will never forget it. This novel also tells us the importance of team work. We can't achieve anything alone. But together we can achieve anything. Although The Institute isn't political in nature, King does raise questions about how modern America treats immigrants, minority groups, and children. 


\section{Works Cited}

Stephen King's The Institute published by Hodder \& Stoughton LtdLondon, 2019 https://www.supersummary.com/the-institute/summary/ https://en.wikipedia.org/wiki/The_Institute_(novel) 